\title{
Adsorptive Removal of Acid Green 20 from Aqueous Solutions by Biomass Ash and Activated Carbon
}

\author{
Abhiti Purai and V. K. Rattan^ \\ Centre for Environment and Vocational Studies, Panjab University Chandigarh-160014, India \\ ^Department of Chemical Engineering and Technology, Panjab University Chandigarh-160014, India \\ e-mail:vkrattanpu@yahoo.com \\ (Received April 2, 2009; Accepted June 18, 2009)
}

\begin{abstract}
Study on the removal of Acid Green 20 by adsorption on indigenously prepared activated carbons from cow dung, mango stone, parthenium leaves and commercial activated carbon have been carried out with an aim to obtain information on treating effluents from tanneries. The effects of various experimental parameters have been investigated by following the batch adsorption technique. Adsorption data was modeled with the Freundlich and Langmuir isotherms. Removal of Acid Green 20 was found to be favorable using Biomass ash and could be considered as alternatives to commercial activated carbon for the treatment of tannery effluents, especially for the removal of dye(s).
\end{abstract}

Keywords : Adsorption, Biomass ash, Activated carbon, Leather dye, Isotherms

\section{Introduction}

Water is a precious natural resource vital for sustaining all life on earth. Ever expanding population and their associated activities compounded by increasing rate of overuse, misuse and abuse of limited freshwater sources over the past few decades have imposed threat on sustainable water development and its management.

Synthetic dyes are widely used in many industries including leather tanning, textile dyeing, paper printing etc. Coloured organic substances generally represent only a small fraction of the total organic load in waste water, however, their high degree of colour is easily detectable [1]. Even at low concentrations disposal of these wastes into the environment could be harmful since they reduce light penetration and have a derogatory effect on photosynthesis. In addition, most dyestuffs are designed to be resistant to environmental conditions such as light, heat and microbial attack.

Various techniques, such as chemical coagulation using alum, lime, ferric chloride, ferric sulphate, biosorption [2] oxidation methods using chloride and $\mathrm{O}_{3}$ [3], membrane separation [4], biological treatment, floatation [5] and adsorption have been employed to remove dyes from industrial effluents.

Activated carbon has been successfully employed for removal of colour from aqueous solution [6]. They are most versatile and unique adsorbents because of their high adsorption capacities, high degree of surface reactivity, extendable surface area and micro porous structure [7]. However, commercial activated carbons are still considered expensive[8] and hence not suitable for developing countries. Currently for such countries, the most suitable technology seems to adsorption onto cheap and abundantly available biomass since this is an eco-friendly and economically feasible dye removal technique [9].

From the related literature, several adsorbents have been reported as dye adsorbents. To name a few, materials such as fly ash [10-14], mango seed and shell [15-16], bagasse [17], sawdust [18-21], coconut shell [22, 23], groundnut husk [24], used waste tea leaves [25] etc. have been reported.

The purpose of the present work was to investigate the potentialities of low cost and easily available bio-wastes i.e. cow dung ash, mango stone ash, parthenium leaves ash and activated carbon for the adsorptive removal of Acid Green 20. The effects of some operating parameters $(\mathrm{pH}$, dye concentration) on the biosorption process were investigated. In addition, the applicability of the Langmuir and Freundlich isotherm models were investigated.

\section{Experimental}

Adsorption studies were performed by the batch technique using biomass ash (low cost bio-waste) and activated carbon as the adsorbents without giving any pretreatment. A stock solution of the dye with a concentration of $1000 \mathrm{mg} / \mathrm{L}$ was prepared and dilutions were made with distilled water to make different concentrations $(10 \sim 100 \mathrm{mg} / \mathrm{L})$ for the adsorption studies. A known weight of the adsorbent $(1 \mathrm{~g})$ was added to $50 \mathrm{~mL}$ of each of the above concentration in $100 \mathrm{~mL}$ 
Table 1. Concentration of dye $\left(\mathrm{C}_{\mathrm{e}}\right)$ and amount of dye adsorbed per gram of the adsorbent $\left(\mathrm{q}_{\mathrm{e}}\right)$ at different $\mathrm{pH}$

\begin{tabular}{|c|c|c|c|c|c|c|c|c|c|c|c|c|}
\hline \multirow[t]{4}{*}{ Adsorbents } & \multicolumn{3}{|c|}{ Cow dung ash } & \multicolumn{3}{|c|}{ Mango stone ash } & \multicolumn{3}{|c|}{ Parthenium leaves ash } & \multicolumn{3}{|c|}{ Carbon } \\
\hline & \multicolumn{12}{|c|}{$\mathrm{q}_{\mathrm{e}}(\mathrm{mg} / \mathrm{g})$} \\
\hline & \multicolumn{3}{|c|}{$\mathrm{pH}$} & \multicolumn{3}{|c|}{$\mathrm{pH}$} & \multicolumn{3}{|c|}{$\mathrm{pH}$} & \multicolumn{3}{|c|}{$\mathrm{pH}$} \\
\hline & 8.63 & 10.20 & 6.59 & 8.63 & 10.20 & 6.59 & 8.63 & 10.20 & 6.59 & 8.63 & 10.20 & 6.59 \\
\hline $\mathrm{C}_{\mathrm{e}}(\mathrm{mg} / \mathrm{L})$ & $\mathrm{q}_{\mathrm{e}}$ & $\mathrm{q}_{\mathrm{e}}$ & $\mathrm{q}_{\mathrm{e}}$ & $\mathrm{q}_{\mathrm{e}}$ & $\mathrm{q}_{\mathrm{e}}$ & $\mathrm{q}_{\mathrm{e}}$ & $\mathrm{q}_{\mathrm{e}}$ & $\mathrm{q}_{\mathrm{e}}$ & $\mathrm{q}_{\mathrm{e}}$ & $\mathrm{q}_{\mathrm{e}}$ & $\mathrm{q}_{\mathrm{e}}$ & $\mathrm{q}_{\mathrm{e}}$ \\
\hline 10 & 0.44 & 0.49 & 0.47 & 0.36 & 0.445 & 0.44 & 0.455 & 0.435 & 0.465 & 0.36 & 0.37 & 0.36 \\
\hline 20 & 0.63 & 0.94 & 0.90 & 0.63 & 0.90 & 0.90 & 0.855 & 0.81 & 0.90 & 0.62 & 0.58 & 0.62 \\
\hline 30 & 1.19 & 1.43 & 1.36 & 1.16 & 1.37 & 1.39 & 1.31 & 1.28 & 1.37 & 0.88 & 0.86 & 0.90 \\
\hline 40 & 1.48 & 1.90 & 1.835 & 1.44 & 1.795 & 1.81 & 1.80 & 1.685 & 1.86 & 1.10 & 1.08 & 1.04 \\
\hline 50 & 1.71 & 2.39 & 2.36 & 1.595 & 2.17 & 2.24 & 2.29 & 2.105 & 2.35 & 1.36 & 1.27 & 1.15 \\
\hline 60 & 2.04 & 2.86 & 2.85 & 1.985 & 2.61 & 2.69 & 2.77 & 2.575 & 2.815 & 1.58 & 1.45 & 1.44 \\
\hline 70 & 2.305 & 3.235 & 3.33 & 2.33 & 3.05 & 3.13 & 3.25 & 2.99 & 3.31 & 1.68 & 1.69 & 1.84 \\
\hline 80 & 2.63 & 3.79 & 3.75 & 2.575 & 3.47 & 3.30 & 3.71 & 3.40 & 3.745 & 1.86 & 1.70 & 2.29 \\
\hline 90 & 3.005 & 4.36 & 4.19 & 2.94 & 3.965 & 3.785 & 4.205 & 3.76 & 4.21 & 2.00 & 1.97 & 1.75 \\
\hline 100 & 3.395 & 4.805 & 4.44 & 3.285 & 4.375 & 4.035 & 4.255 & 4.015 & 4.375 & 2.32 & 2.07 & 2.00 \\
\hline
\end{tabular}

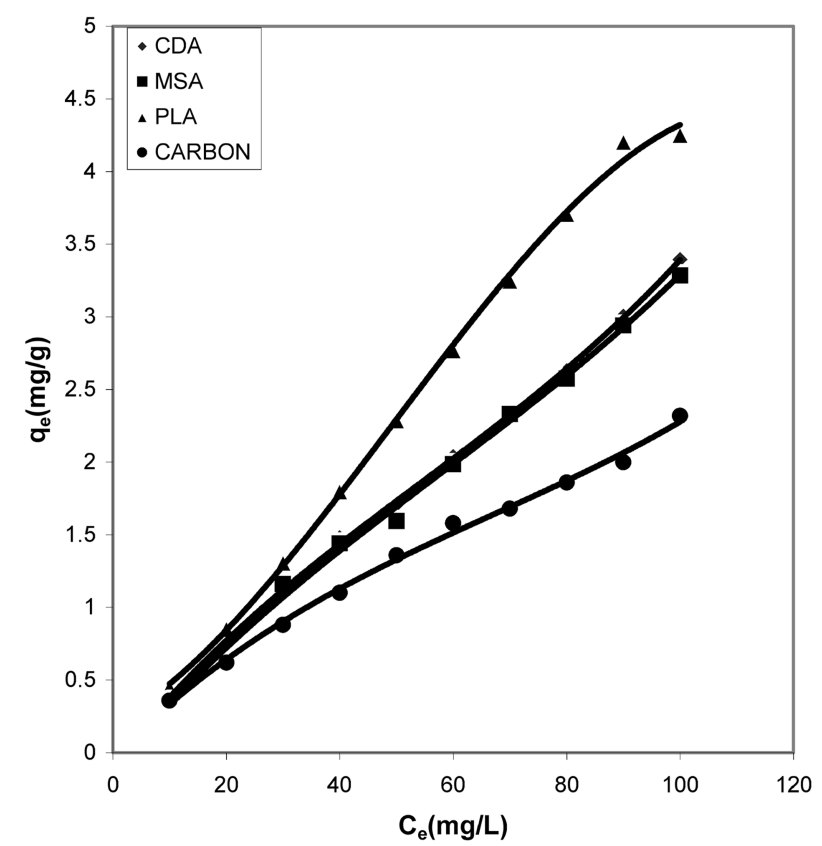

Fig. 1. Adsorption isotherm of Acid Green 20 at $\mathrm{pH} 8.63$.

measuring flasks. These were placed in an air thermostat for 24 hrs. with occasional shaking. The samples were then filtered and analyzed using UV-spectrophotometer. Wavelengths of different dyes were determined by $\lambda_{\max }$ method. The $\mathrm{pH}$ values of solutions were adjusted by addition of $\mathrm{H}_{2} \mathrm{SO}_{4}$ and $\mathrm{NaOH}$.

\section{Results and Discussion}

\subsection{Effect of initial dye concentration}

Amount of dye adsorbed is tabulated in Table 1 from which it is seen that with a constant adsorbent dose of $1 \mathrm{~g} /$

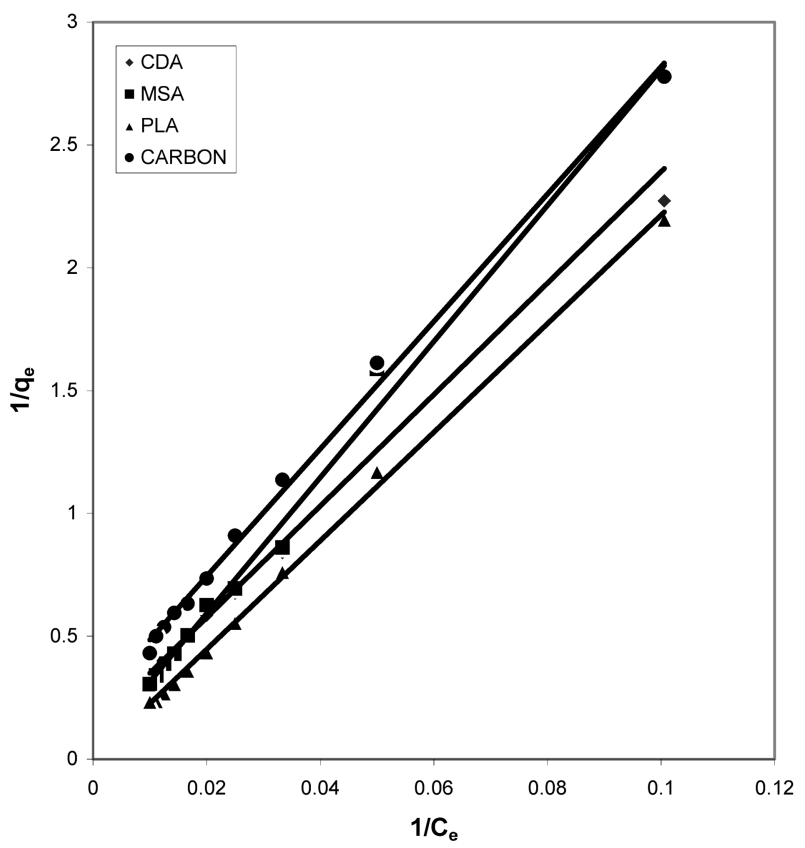

Fig. 2. Langmuir isotherm of Acid Green 20 at $\mathrm{pH} 8.63$.

$50 \mathrm{ml}$ of dye solution, the amount of dye adsorbed per gram of adsorbents increases with the increase in the dye concentration. The data shows that adsorption on bio-wastes was more than activated carbon and they adsorbed a fairly good amount of residual dye Acid Green 20 from wastewater.

\subsection{Effect of $\mathrm{pH}$}

The $\mathrm{pH}$ has a marked effect on the adsorption of dyes. At different $\mathrm{pH}$ values the amount adsorbed per gram of adsorbent is different. It is seen from Table 1 that cow dung and mango stone ash adsorbed better at strong basic $\mathrm{pH}$ i.e. $10.20(4.805 \mathrm{mg} / \mathrm{g}$ and $4.375 \mathrm{mg} / \mathrm{g})$ while adsorption was less 


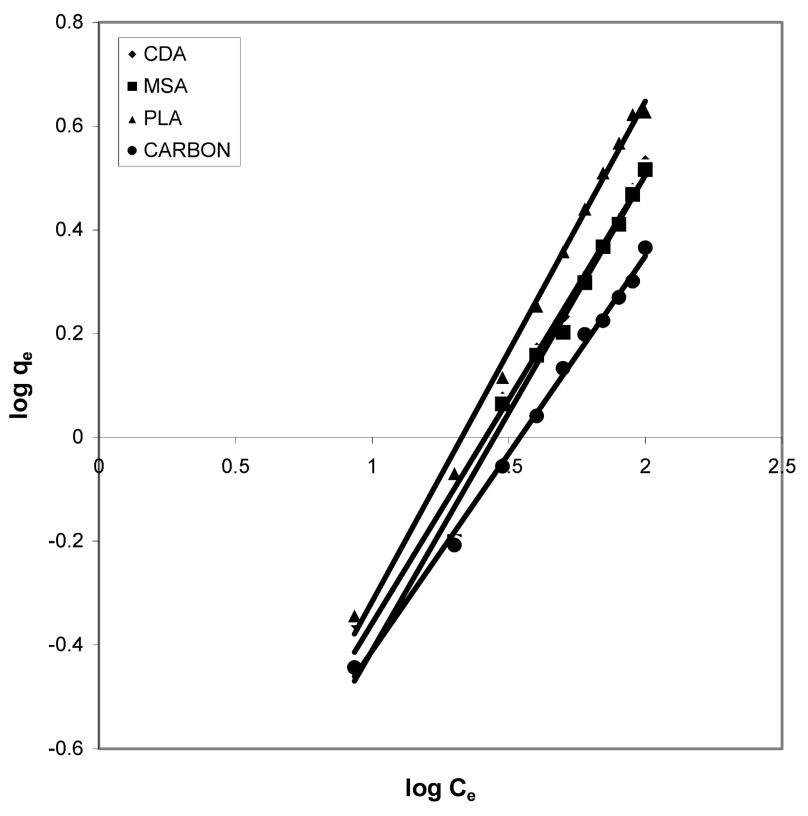

Fig. 3. Freundlich isotherm of Acid Green 20 at $\mathrm{pH} 8.63$.

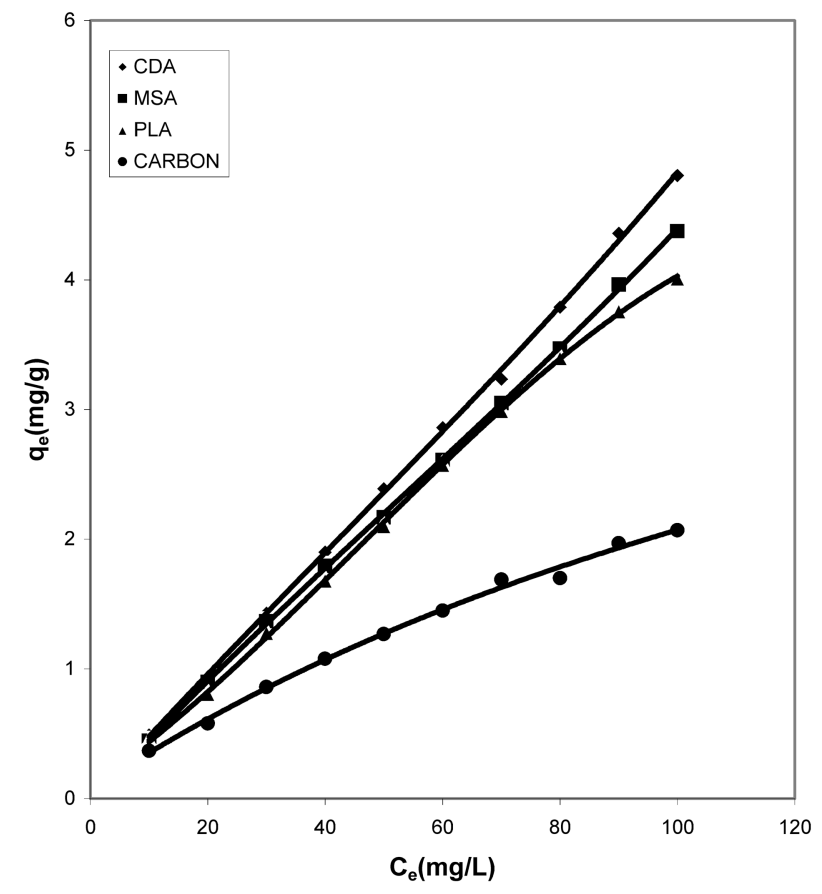

Fig. 4. Adsorption isotherm of Acid Green 20 at pH 10.20.

at the other two $\mathrm{pH}$ values, $8.63(3.395 \mathrm{mg} / \mathrm{g}$ and $3.285 \mathrm{mg} / \mathrm{g})$ and $6.59(4.44 \mathrm{mg} / \mathrm{g}$ and $4.035 \mathrm{mg} / \mathrm{g})$. For parthenium leaves ash $\mathrm{pH} 6.59$ suited more $(4.375 \mathrm{mg} / \mathrm{g})$ while for activated carbon it showed least adsorption capacity $(2.0 \mathrm{mg} / \mathrm{g})$.

\subsection{Data fit for Simple Isotherms}

It can be seen from Figs. 1, 4, 7 that the experimental data

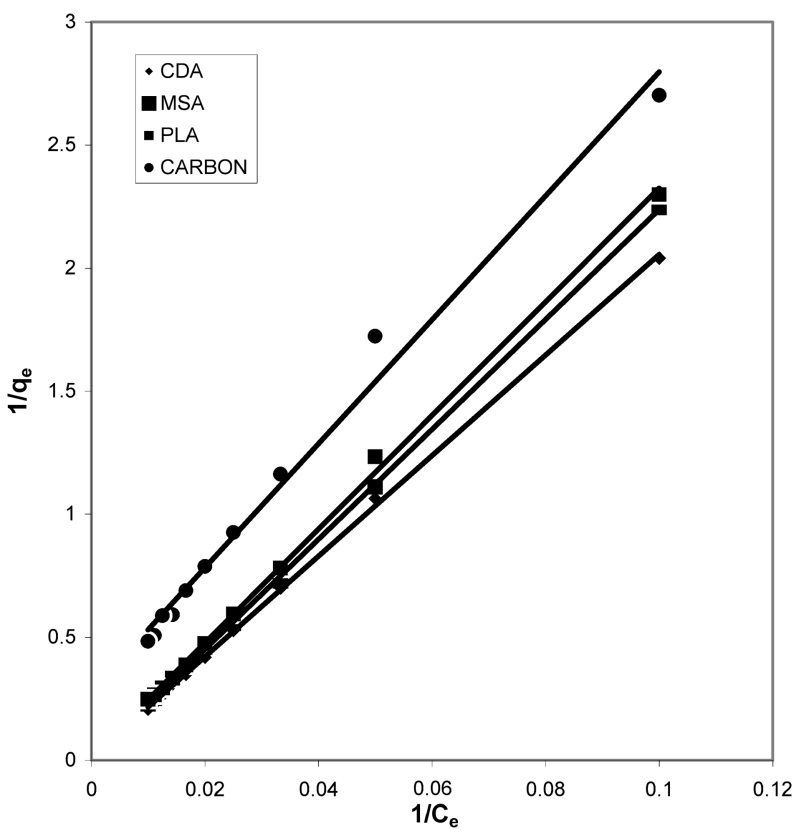

Fig. 5. Langmuir isotherm of Acid Green 20 at pH 10.20.

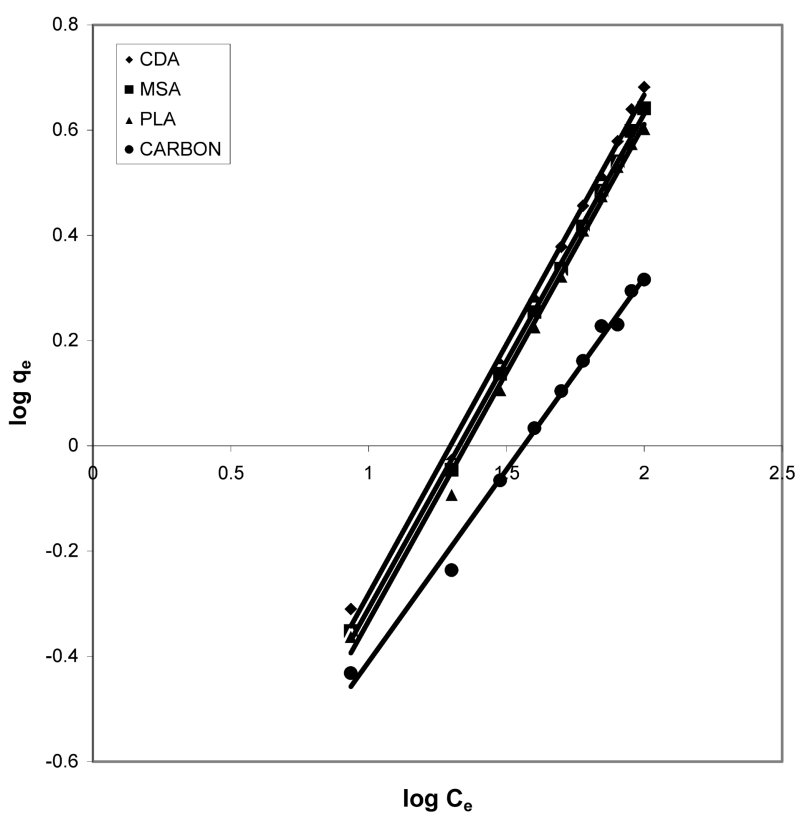

Fig. 6. Freundlich isotherm of Acid Green 20 at pH 10.20.

fitted well to the Polynomial Equation 1. The constants and standard deviation are given in Table 2. Comparative adsorption of Acid Green 20 on the various adsorbents used at varied $\mathrm{pH}$ values is shown in Figs. 1, 4, 7. Maximum dye removal was observed at $\mathrm{pH} 10.20$. Activated carbon showed the least adsorption efficiency as compared to the biomass ash i.e. cow dung, mango stone and parthenium leaves ash.

Cow dung and mango stone ash (Figs. 10 and 11) exhibit most favorable adsorption under strong alkaline condition 
Table 2. Values of different constants for polynomial fit data

\begin{tabular}{|c|c|c|c|c|c|c|c|c|c|c|c|c|}
\hline \multirow{3}{*}{$\begin{array}{c}\begin{array}{c}\text { Adsor- } \\
\text { bents }\end{array} \\
\begin{array}{c}\text { Parame- } \\
\text { ter }\end{array}\end{array}$} & \multicolumn{3}{|c|}{ Cow dung ash } & \multicolumn{3}{|c|}{ Mango stone ash } & \multicolumn{3}{|c|}{ Parthenium leaves ash } & \multicolumn{3}{|c|}{ Carbon } \\
\hline & \multicolumn{3}{|c|}{$\mathrm{pH}$} & \multicolumn{3}{|c|}{$\mathrm{pH}$} & \multicolumn{3}{|c|}{$\mathrm{pH}$} & \multicolumn{3}{|c|}{$\mathrm{pH}$} \\
\hline & 6.59 & 8.63 & 10.20 & 6.59 & 8.63 & 10.20 & 6.59 & 8.63 & 10.20 & 6.59 & 8.63 & 10.20 \\
\hline $\mathrm{A}$ & 0.1285 & -0.065 & -0.015 & -0.053 & -0.0991 & -0.0308 & 0.1325 & 0.205 & 0.09883 & 0.38567 & -0.024 & 0.07067 \\
\hline $\mathrm{B}_{1}$ & 0.03093 & 0.04797 & 0.05031 & 0.04905 & 0.04626 & 0.04931 & 0.0306 & 0.02106 & 0.03112 & -0.002 & 0.03898 & 0.02948 \\
\hline $\mathrm{B}_{2}$ & $4.18 \mathrm{E}-4$ & $-3.4 \mathrm{E}-4$ & $-9.11 \mathrm{E}-5$ & $-3.1 \mathrm{E}-5$ & $-2.9 \mathrm{E}-4$ & $-1.3 \mathrm{E}-4$ & $4.28 \mathrm{E}-4$ & $6.28 \mathrm{E}-4$ & $3.00 \mathrm{E}-4$ & $6.40 \mathrm{E}-4$ & $-3.16 \mathrm{E}-4$ & $-1.23 \mathrm{E}-4$ \\
\hline $\mathrm{B}_{3}$ & $-2.95 \mathrm{E}-6$ & $2.122 \mathrm{E}-6$ & $7.2358 \mathrm{E}-7$ & $-4.9 \mathrm{E}-7$ & $1.69 \mathrm{E}-6$ & $8.67 \mathrm{E}-7$ & $-3.0 \mathrm{E}-6$ & $-4.2 \mathrm{E}-6$ & $-2.1 \mathrm{E}-6$ & $-4.6 \mathrm{E}-6$ & $1.569 \mathrm{E}-6$ & $2.85 \mathrm{E}-7$ \\
\hline $\mathrm{R}^{2}$ & 0.99985 & 0.99628 & 0.9994 & 0.99838 & 0.99623 & 0.99976 & 0.99936 & 0.99845 & 0.99978 & 0.92907 & 0.99613 & 0.99527 \\
\hline SD & 0.0207 & 0.07311 & 0.04351 & 0.0603 & 0.07281 & 0.02508 & 0.0429 & 0.06609 & 0.02255 & 0.20528 & 0.04805 & 0.04864 \\
\hline
\end{tabular}

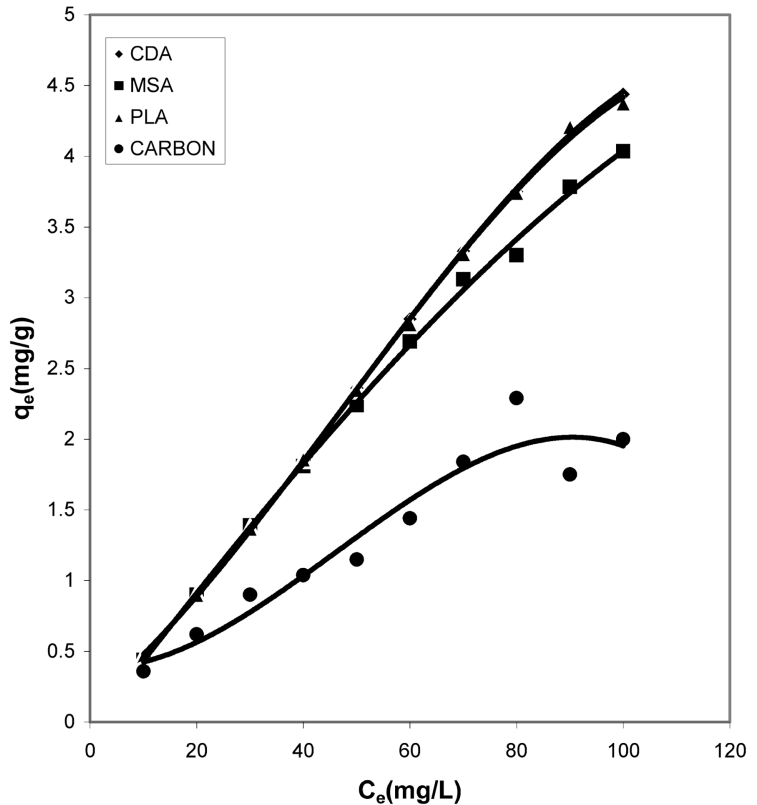

Fig. 7. Adsorption isotherm of Acid Green 20 at pH 6.59 .

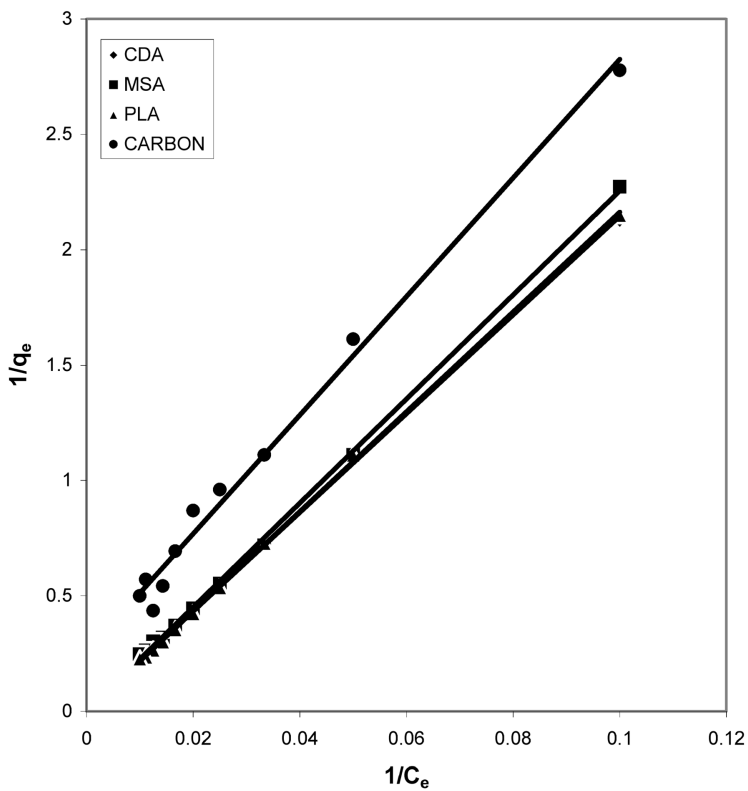

Fig. 8. Langmuir isotherm of Acid Green 20 at pH 6.59.

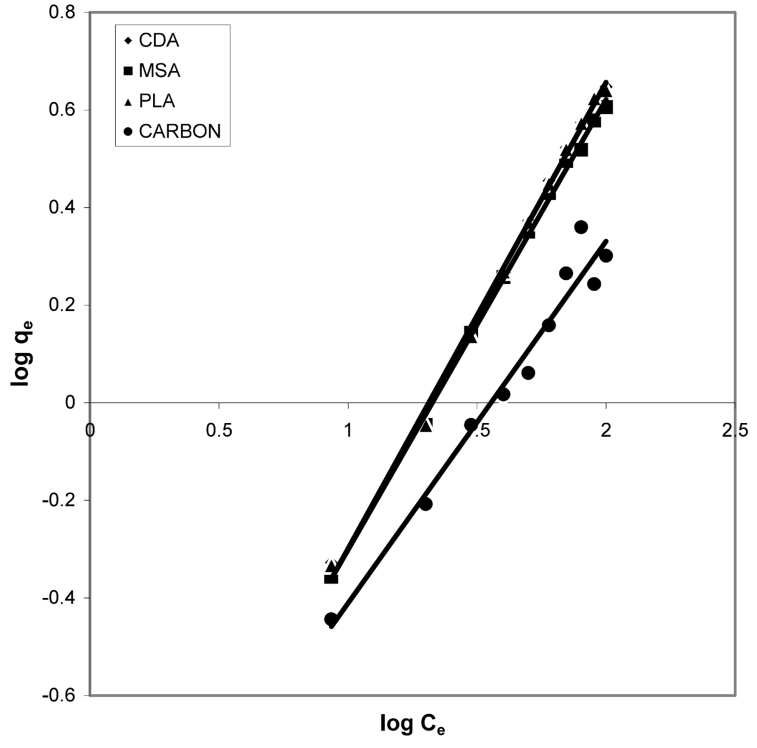

Fig. 9. Freundlich isotherm of Acid Green 20 at pH 6.59.

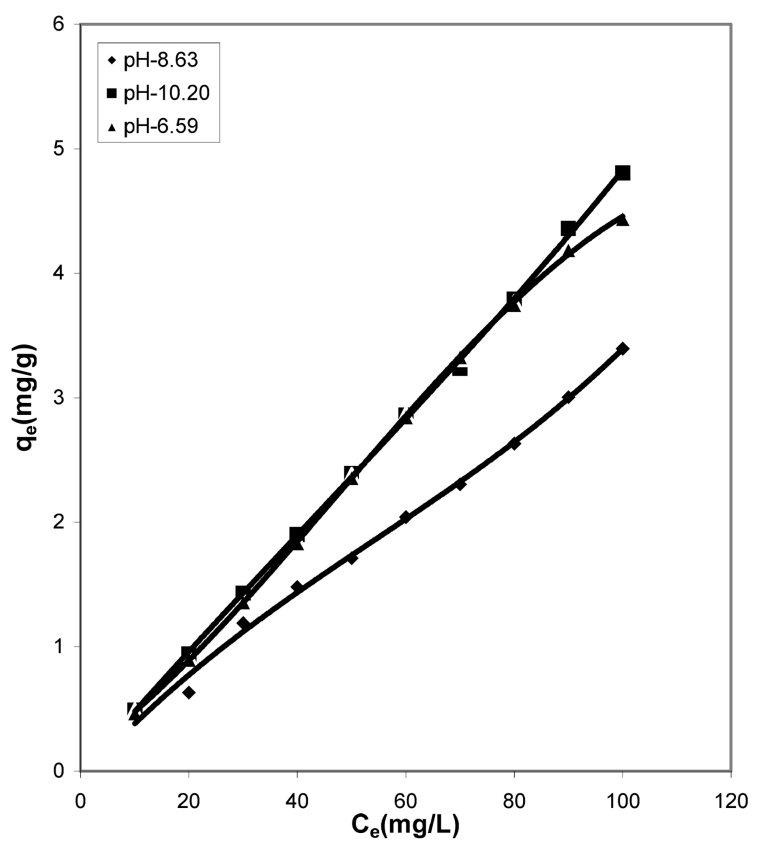

Fig. 10. Adsorption isotherms of Acid Green 20 for cow dung ash at $\mathrm{pH} 8.63,10.20$ and 6.59 . 


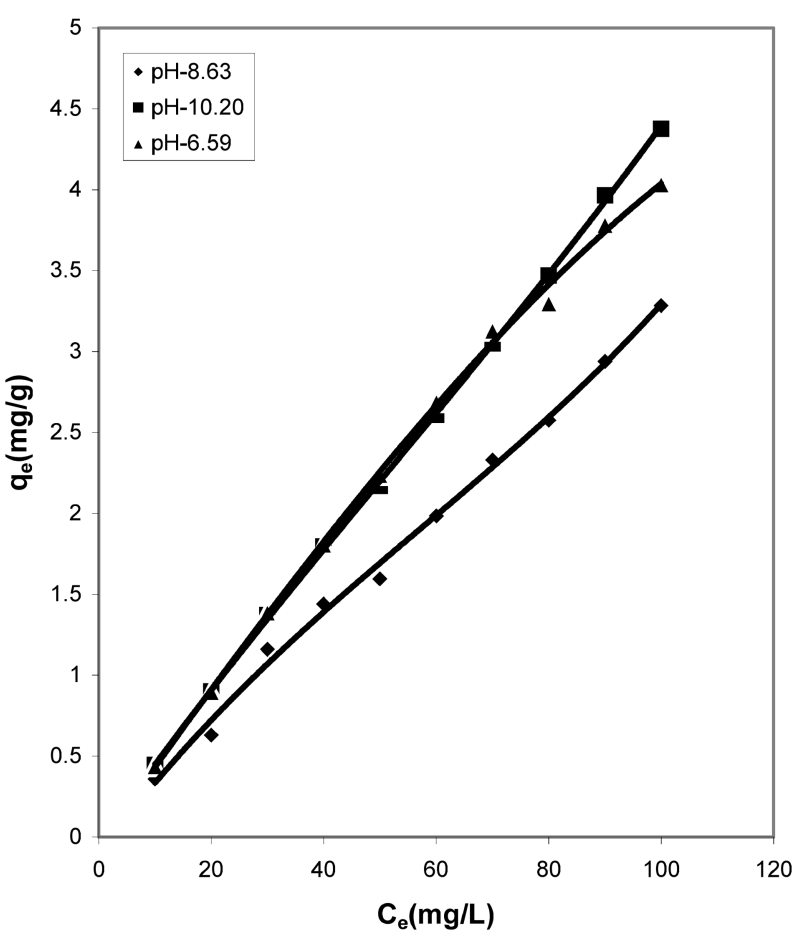

Fig. 11. Adsorption isotherms of Acid Green 20 for mango stone ash at $\mathrm{pH} 8.63,10.20$ and 6.59 .

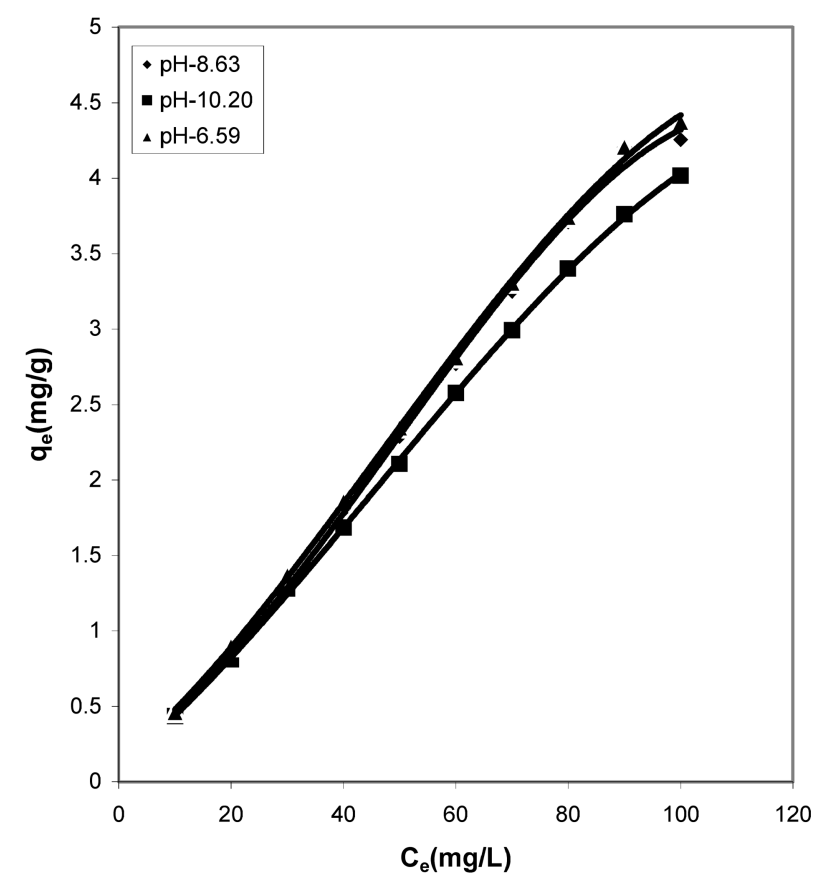

Fig. 12. Adsorption isotherms of Acid Green 20 for parthenium leaves ash at $\mathrm{pH} 8.63,10.20$ and 6.59 .

(pH 10.20) whereas at $\mathrm{pH} 8.63$ adsorption is least. From Fig. 12 it is seen that where at $\mathrm{pH} 10.20$ cow dung and mango stone ash show maximum adsorption efficiency, parthenium leaves ash shows the least, the best being at around neutral

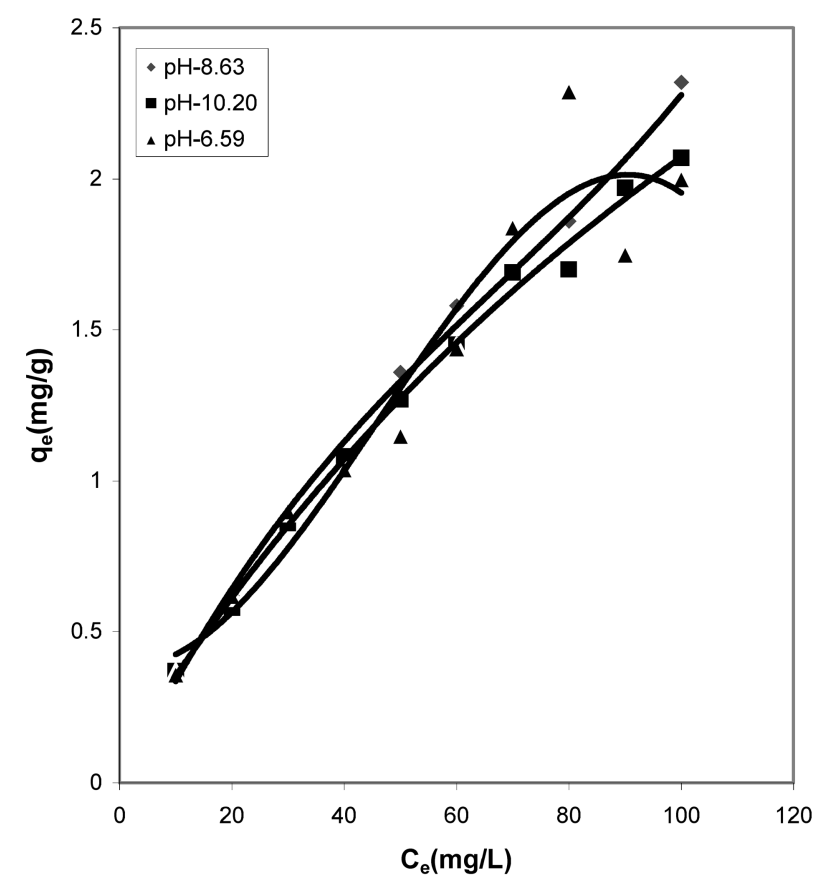

Fig. 13. Adsorption isotherms of Acid Green 20 for carbon at $\mathrm{pH} 8.63,10.20$ and 6.59.

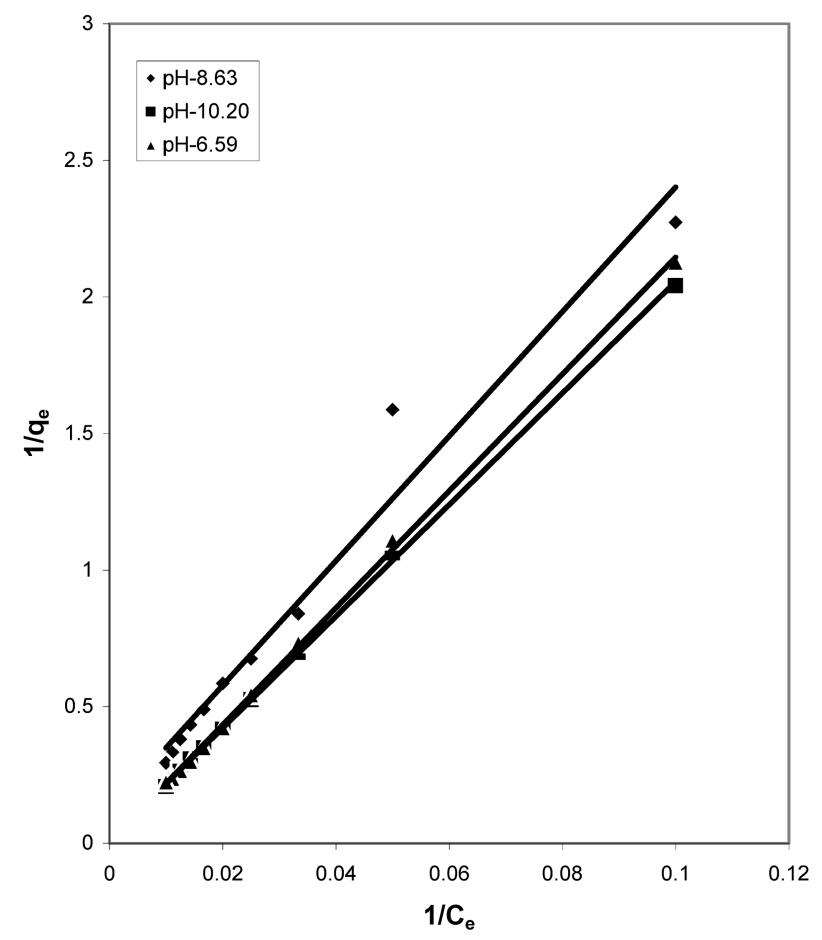

Fig. 14. Langmuir isotherms of Acid Green 20 for cow dung ash, at $\mathrm{pH} 8.63,10.20$ and 6.59 .

$\mathrm{pH}$ value of 6.59. At $\mathrm{pH} 10.20$ and 8.63 adsorption trend is almost similar. For activated carbon (Fig. 13) adsorption gets quite linear at $\mathrm{pH} 8.63$ and 10.20 but at $\mathrm{pH} 6.59$ it gives an almost S-shape curve showing least adsorption at the highest 


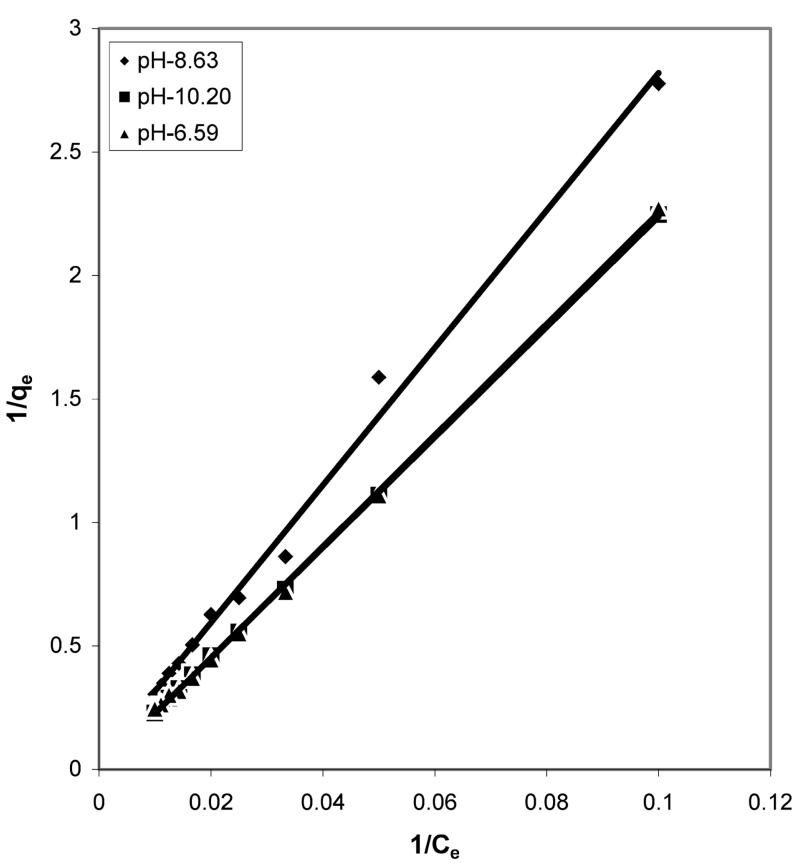

Fig. 15. Langmuir isotherms of Acid Green 20 for mango stone ash, at $\mathrm{pH} 8.63,10.20$ and 6.59 .

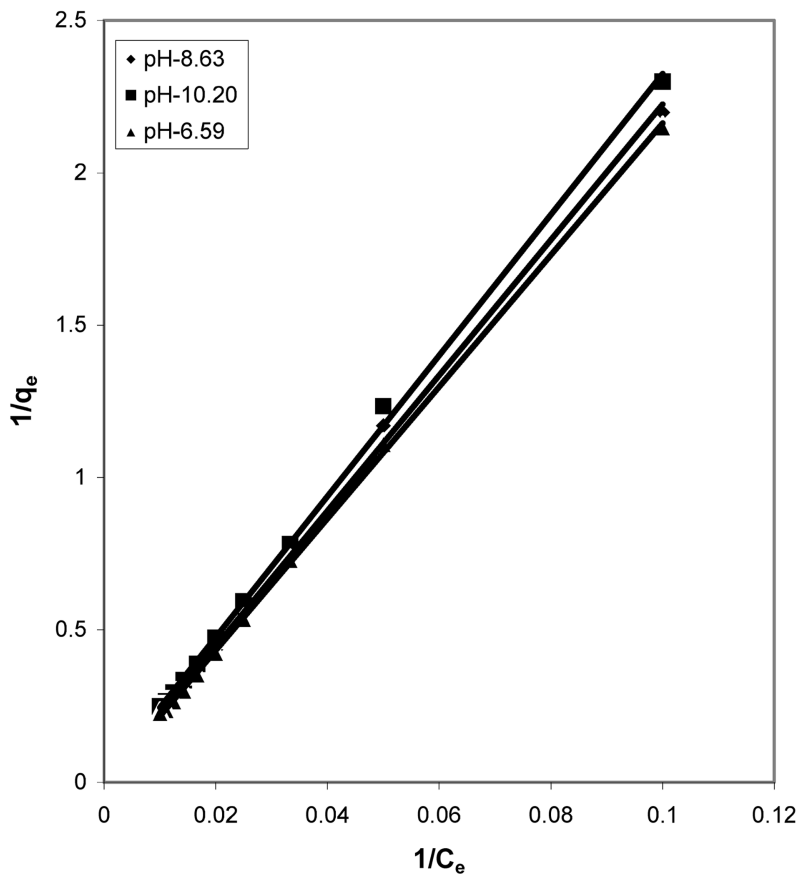

Fig. 16. Langmuir isotherms of Acid Green 20 parthenium leaves ash at $\mathrm{pH} 8.63,10.20$ and 6.59.

dye concentration.

\subsection{Langmuir isotherms at various $\mathrm{pH}$}

From the slope and intercept of linear plots between $1 / q_{e}$

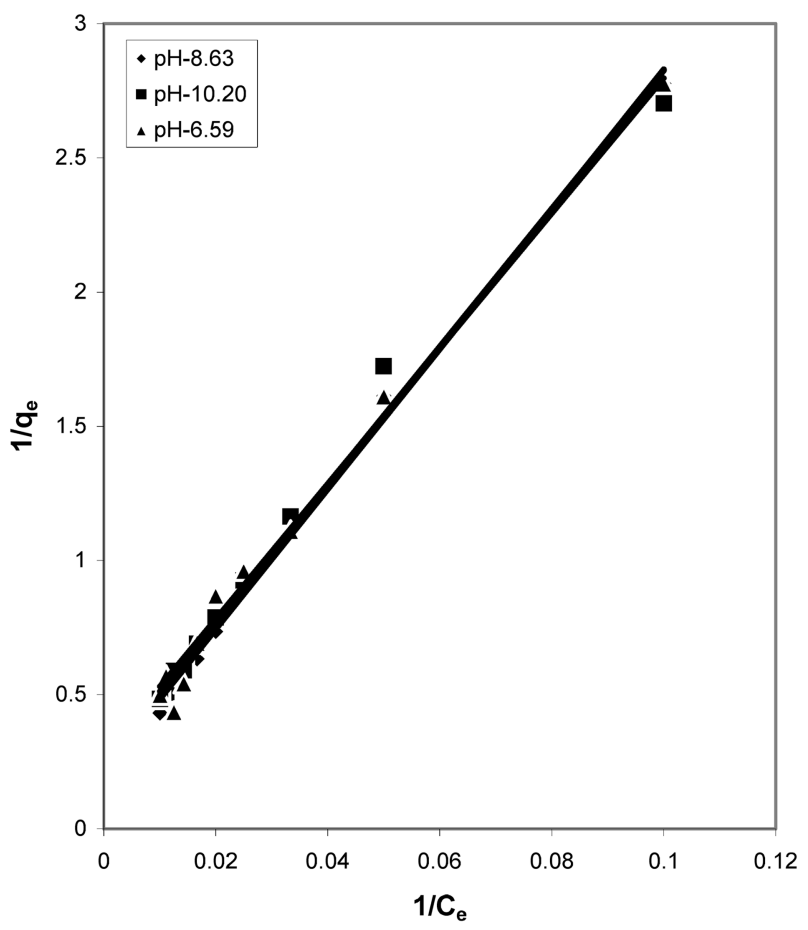

Fig. 17. Langmuir isotherms of Acid Green 20 carbon at $\mathrm{pH}$ $8.63,10.20$ and 6.59 .

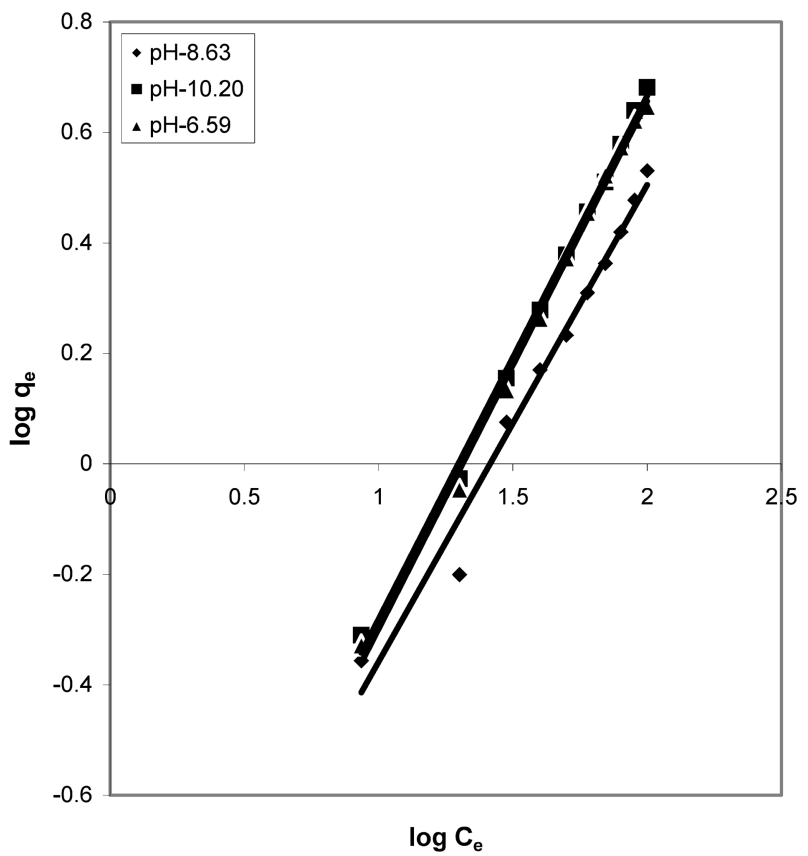

Fig. 18. Freundlich isotherms of Acid Green 20 cow dung ash, at $\mathrm{pH} 8.63,10.20$ and 6.59 .

and 1/Ce as shown in Figs. 2, 5 and 8 and also Figs. 14 17 Langmuir constants "Q" and " $b$ " were calculated. These values along with $\mathrm{R}$ and standard deviation are given in Table 3. Seeing the data it can be said that adsorption was favorable. Different values of $\mathrm{Q}$ are explained by varying 
Table 3. Values of different constants for Langmuir isotherms at various $\mathrm{pH}$

\begin{tabular}{|c|c|c|c|c|c|c|c|c|c|c|c|c|}
\hline \multirow{3}{*}{$\begin{array}{l}\text { Adsorbents } \\
\text { Parameter }\end{array}$} & \multicolumn{3}{|c|}{ Cow dung ash } & \multicolumn{3}{|c|}{ Mango stone ash } & \multicolumn{3}{|c|}{ Parthenium leaves ash } & \multicolumn{3}{|c|}{ Carbon } \\
\hline & \multicolumn{3}{|c|}{$\mathrm{pH}$} & \multicolumn{3}{|c|}{$\mathrm{pH}$} & \multicolumn{3}{|c|}{$\mathrm{pH}$} & \multicolumn{3}{|c|}{$\mathrm{pH}$} \\
\hline & 6.59 & 8.63 & 10.20 & 6.59 & 8.63 & 10.20 & 6.59 & 8.63 & 10.20 & 6.59 & 8.63 & 10.20 \\
\hline $\mathrm{R}$ & 0.99964 & 0.98235 & 0.99976 & 0.99989 & 0.99626 & 0.99989 & 0.99978 & 0.99927 & 0.99929 & 0.99472 & 0.99819 & 0.99401 \\
\hline SD & 0.01701 & 0.12773 & 0.01315 & 0.00972 & 0.07098 & 0.00972 & 0.01325 & 0.02506 & 0.02563 & 0.07798 & 0.04622 & 0.08144 \\
\hline Q & 176.9911 & 8.25900 & 80.19246 & 8.36890 & 27.7008 & 242.7184 & 684.9315 & 377.358 & 66.97923 & 3.92018 & 4.4762 & 3.5871 \\
\hline b & 0.120910 & 2.76210 & 0.25477 & 2.6933 & 1.00491 & 0.09206 & 0.031556 & 0.05887 & 0.34488 & 6.55630 & 5.82280 & 7.0198 \\
\hline
\end{tabular}

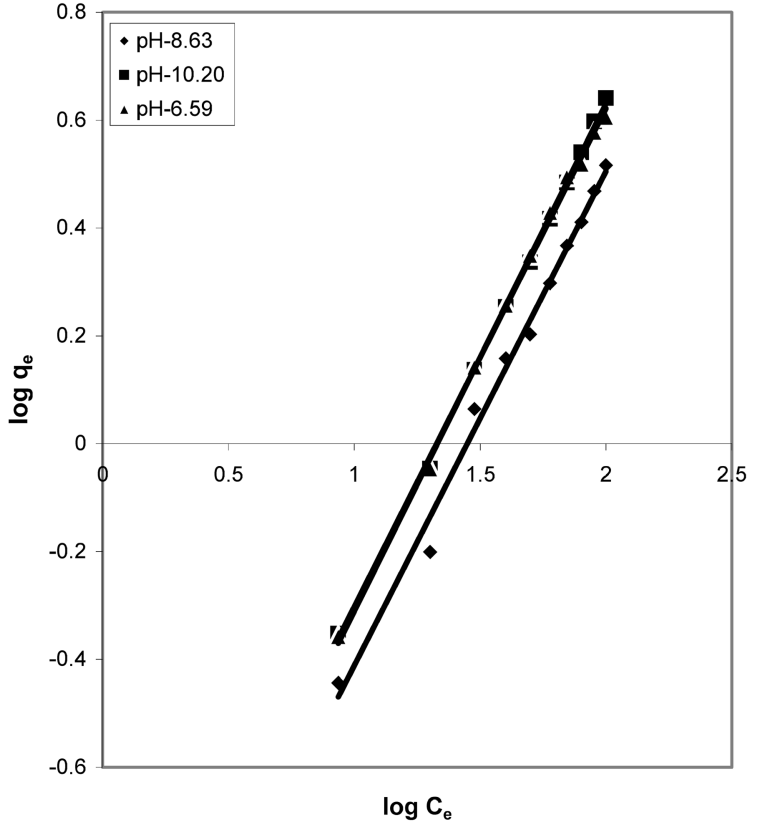

Fig. 19. Freundlich isotherms of Acid Green 20 for mango stone ash at $\mathrm{pH} 8.63,10.20$ and 6.59 .

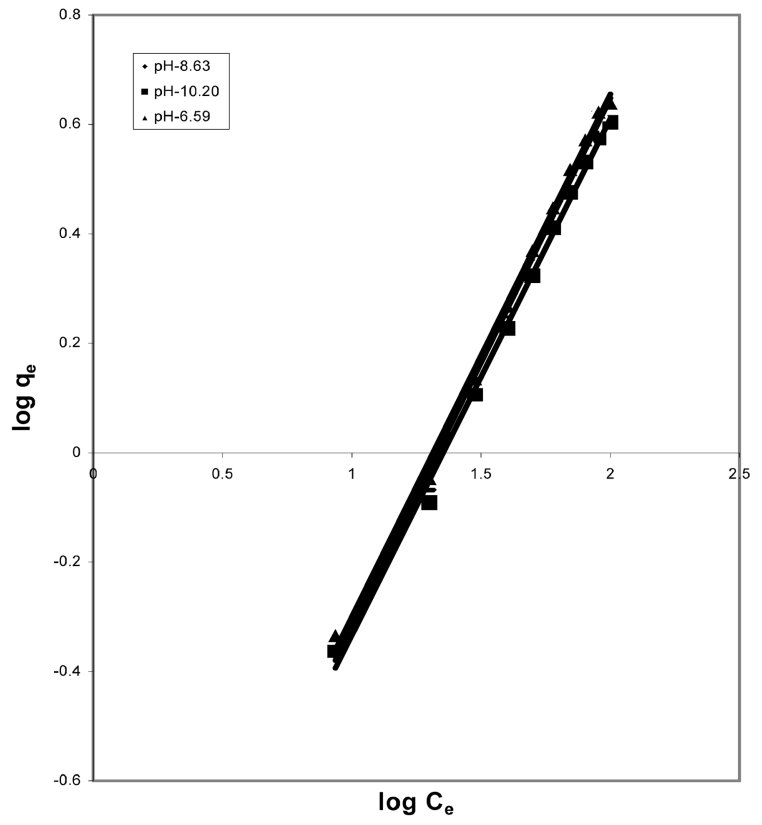

Fig. 20. Freundlich isotherms of Acid Green 20 for parthenium leaves ash at $\mathrm{pH} 8.63,10.20$ and 6.59 .

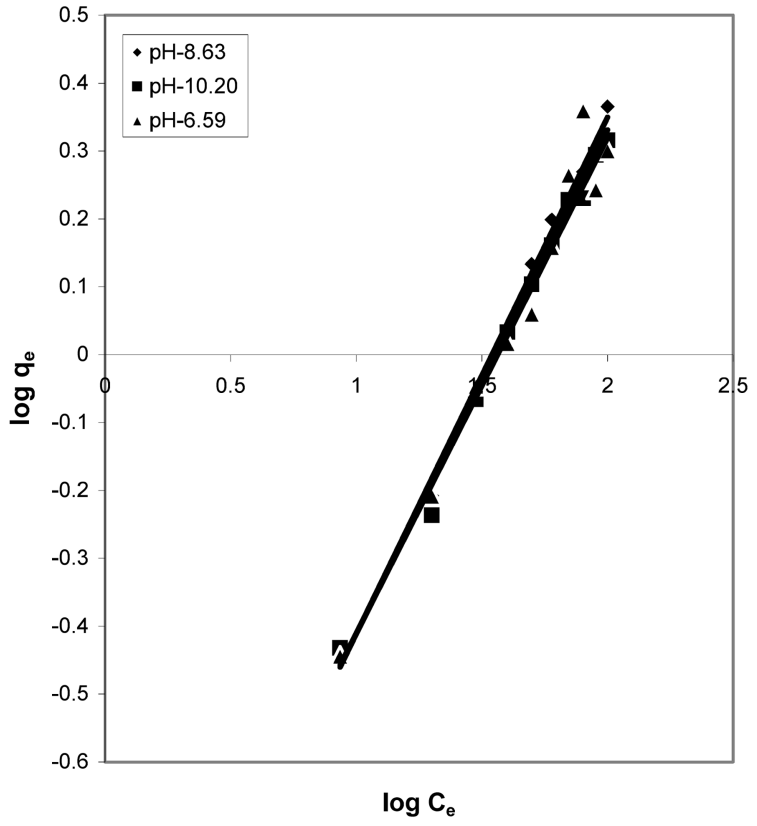

Fig. 21. Freundlich isotherms of Acid Green 20 for carbon at $\mathrm{pH} 8.63,10.20$ and 6.59 .

affinity of dye towards the adsorbents.

\subsection{Freundlich isotherm at various $\mathrm{pH}$}

Figs. 3, 6 and 9 and also Figs. 18-21 show the linear plots of Freundlich isotherm $\log \mathrm{q}_{\mathrm{e}}$ and $\log \mathrm{C}_{\mathrm{e}}$. Freundlich constants $\mathrm{K}_{\mathrm{F}}$ and $\mathrm{n}$ calculated from the slope and intercept along with $\mathrm{R}$ and SD are given in Table 4.

\section{Conclusions}

Biosorption batch studies onto cow dung, mango stone ash, parthenium leaves ash and activated carbon have been performed in the present work employing Acid Green 20. Results indicate that there is a decrease in the percentage of dye removal of the dye per gram with increase in dye concentration. The $\mathrm{pH}$ of the aqueous solution played a significant role in affecting the adsorption capacity of the dye. The value of dimensionless separation factor $\mathrm{R}$ indicates that both adsorption isotherm models fitted satisfactorily and 
Table 4. Values of different constants for Freundlich isotherms at various $\mathrm{pH}$

\begin{tabular}{|c|c|c|c|c|c|c|c|c|c|c|c|c|}
\hline \multirow{3}{*}{$\begin{array}{l}\text { Adsorbents } \\
\text { Parameter }\end{array}$} & \multicolumn{3}{|c|}{ Cow dung ash } & \multicolumn{3}{|c|}{ Mango stone ash } & \multicolumn{3}{|c|}{ Parthenium leaves ash } & \multicolumn{3}{|c|}{ Carbon } \\
\hline & & $\mathrm{pH}$ & & & $\mathrm{pH}$ & & & $\mathrm{pH}$ & & & $\mathrm{pH}$ & \\
\hline & 6.59 & 8.63 & 10.20 & 6.59 & 8.63 & 10.20 & 6.59 & 8.63 & 10.20 & 6.59 & 8.63 & 10.20 \\
\hline $\mathrm{R}$ & 0.99808 & 0.98989 & 0.99836 & 0.99914 & 0.99546 & 0.99939 & 0.99835 & 0.99716 & 0.99805 & 0.98258 & 0.99828 & 0.99656 \\
\hline SD & 0.02098 & 0.04376 & 0.01924 & 0.01353 & 0.03097 & 0.01163 & 0.0194 & 0.02581 & 0.02088 & 0.04963 & 0.01582 & 0.02146 \\
\hline $\mathrm{K}_{\mathrm{F}}$ & 0.28518 & 0.29447 & 0.29236 & 0.29377 & 0.26528 & 0.28654 & 0.28515 & 0.27694 & 0.27877 & 0.315555 & 0.30955 & 0.31968 \\
\hline $\mathrm{n}$ & 1.04646 & 1.1577 & 1.05475 & 1.08342 & 1.09159 & 1.06362 & 1.04707 & 1.03528 & 1.05916 & 1.34747 & 1.31393 & 1.37033 \\
\hline
\end{tabular}

suggested monolayer coverage on the outer surface of the adsorbent and the same also suggests that Langmuir gave a better fit. The different values of $\mathrm{Q}$ are explained by the varying degree of interaction between the adsorbate and the adsorbent. Consequently, safely can point to the use of these natural, ecofriendly materials due to their abundance and cheap biomass to minimize the burden of waste on the environment. This leads to their superiority as a potential sorbent in removal of some coloured dyes from wastewaters.

\section{References}

[1] McKay, G. J. Chem. Biotechnol. 1982, 32, 759.

[2] Low, K. S.; Lee C. K.; Heng, L.L. Environ. Technol. 1994, $15,115$.

[3] Churchley, J. H. Sci. Tech. 1994, 30, 275.

[4] Grossley, C. In: Cooper P. Ed. "Society of Dyes and Colourists," Bradford, 1995.

[5] Weber, Jr, W. J. "Physico-chemical Methods of Treatment of Water and Wastewater," New York: JohnWiley \& Sons Inc., 1978.

[6] Sun, G.; Xu, X. Ind. Eng. Chem. Res. 1997, 36, 808.

[7] Wahab, Ola Abdel.; Nemr, Ahmed El.; Sikaily, Amany El; Khaled, Azza. Egyptian Journal of Aquatic Research 2005, 31,1 .

[8] Chakraborty, S.; De, S.; DasGupta, S.; Basu, J. K. Chemosphere 2005, 58, 1079.

[9] Churchley, J. H.; Greaves, A. J.; Hutchings, M. G.; James, A. E.; Phillips, D. A. S., Water Research 2000, 34, 1673.
[10] Khanna, P.; Malhotra, S. K. Indian J. Env. Hlth. 1977, 19, 224.

[11] Ramu, A.; Kannan, N.; Srivathsan, S. A. Indian J. Env. Hlth. 1992, 34, 192.

[12] Singh, R. D.; Rawat, N. S. 1993, 35, 262.

[13] Mall, I. D.; Upadhyay, S. N. Indian J. Env. Hlth. 1998, 40, 177.

[14] Rao, M.; Bhole, A. G. Journal of Indian Water Works Association 2001, 33, 97.

[15] Mohammad, Ali.; Mohammad, Ajmal.; Rehana, Yousuf.; Anees, Ahmed. Indian J. Chem. Technol. 1997, 4, 223.

[16] Ajmal Mohammad, A.; Mohammad, R.; Yousuf, A. Ahmed. Indian J. Env. Hlth. 1998, 40, 15.

[17] Chand, S.; Agrawal, V. K.; Kumar, Pavan. Indian J. Env. Hlth. 1994, 36, 151.

[18] Khagesan, P.; Srinivas Rao, P.; Shivraj, P. Journal of the IPHE 1991, 2, 20.

[19] Raji, C.; Shubha, K. P.; Anirudhan, T. S. Indian J. Env. Hlth. 1997, 39, 230.

[20] Raji, C.; Anirudhan, T. S. Indian J. Chem. Technol. 1997, 4, 228.

[21] Rao, M.; Bhole, A. G. Journal IAEM 2000, 27, 291.

[22] Joseph, K.; Rajenthiran, V. Indian J. Env. Hlth. 1995, 37, 72.

[23] Muthukumaran, N.; Balasubrahmanian, N.; Rama Krishna, T. V. Journal IAEM 1995, 22, 136.

[24] Periasamy, K.; Srinivasan, K.; Murugan, P. K. Indian J. Env. Hlth, 1999, 33, 433.

[25] Singh, D. K.; Tiwari, D. P.; Saksena, D. N. Indian J. Env. Hlth. 1993, 35, 69. 